\title{
Agricultural cooperation among the North-East Asian countries
}

\author{
Byung-Oh Lee* \\ Department of Agricultural \& Resource Economics, Kangwon National University, Chuncheon 200-701, Korea
}

Received on 13 November 2012, revised on 8 February 2013, accepted on 25 February 2013

\begin{abstract}
The following four aspects should be examined in detail to revitalize North-East Asian agricultural cooperation specialized with Korea, Japan, and China.First, quality and safety standards of agricultural food should be unified. Secondly, it is necessary to build a food security cooperative system in North-East Asia. If three countries build the system, they can overcome a problem such as unstable supply and demand due to natural disaster, and also they can cope with food crisis.Thirdly, to establish North-East Asian Agro-valley is needed. After forming food production belt that connects Korea, Hokkaido in Japan, and the three north-eastern provinces in China, it is possible to realize high value-added agriculture with producing and processing of complementary food for partner country.Lastly, trilateral FTA negotiations should be managed carefully with operating the agricultural special zone and exclusion or prolong period of removal of tariff on sensitive items.
\end{abstract}

Key words : Agricultural cooperation, North-East Asia, Agro-valley, FTA

\section{Introduction}

Korea, China, and Japan are located geopolitically in the North-east Asia and have actively conducted political, economical, social, and cultural exchanges. Especially, agriculture is heavily influenced by the weather and climate, hence these three countries have similarities in the type of agricultural products and the method of cultivation. Since most of the agricultural products become food materials, the dietary structures are similar with rice and vegetables.

Agricultural trade has been actively conducted among the three countries for a long time and since WTO system, it has been expedited. Through the agricultural trade among the three countries located in near distances to one another, the importing countries can get fresh agricultural products in a short time at the low delivery cost, and the exporting countries can increase the agricultural income by providing better conditions than other competitors.

*Corresponding author: Tel: +82-33-250-8662

E-mail address: bolee@kangwon.ac.kr

\section{Materials and Methods}

As shown in Figure 1, since the later part of the 1990s, the international trade environment has favoured free trade among multiple parties through WTO negotiation and changed toward the reinforcement of the economic cooperation between two countries or in certain areas through FTA. In particular, Europe and North America built two axes to establish huge economic blocks. Compared to this, the three countries in charge of main status in the Asian economy are one step aside.

The three countries with different sizes and developmental stages of agriculture inevitably face trade conflicts with the increase of trade. Some exported items cause detrimental impacts on the main cultivation sites in the counterpart country and trade conflicts occurs with the safety issue. Compared to those of Korea and Japan, the competitiveness of the Chinese agriculture is strong. Therefore, 'trade' is based on 'cooperation' and at the same time accompanies 'competition'.

However, it is desirable to actively respond to the 


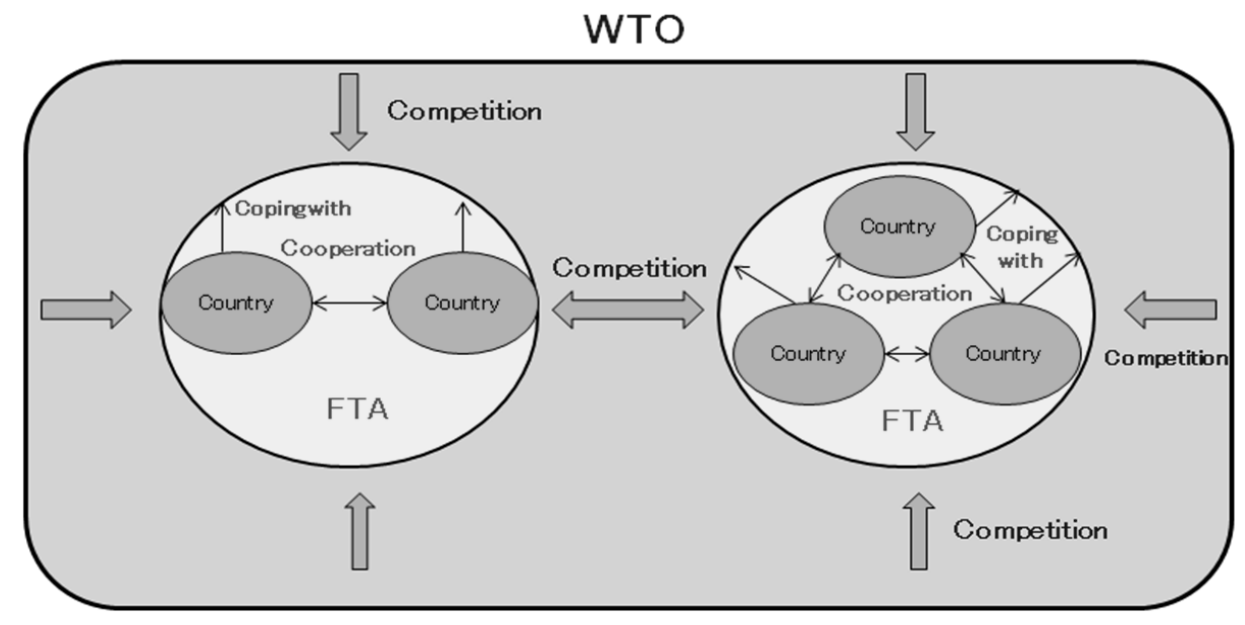

Fig. 1. Competition and Cooperation in WTO and FTA.

international trade environment, reinforce the economic cooperation among three countries and firmly establish one axis of the Asian economy and it should be reminded that it is necessary for the development of three countries as well as the stable development of the world economy. For this point, agriculture is not an exception. Three countries can pursue the co-prosperity through the proper 'competition' and 'cooperation' at the same time.

In this paper, based on this point of view, I want to present the directions of agricultural cooperation among the North-east Asian countries.

\section{Results}

\section{The structure of agriculture in Korea, China, and Japan}

\section{(1) Geopolitical characteristics of North-East Asia}

As shown in Figure 2, economic blocks have expanded in the world. Main economic blocks contain 27 European countries' EU, 3 North American countries' NAFTA,

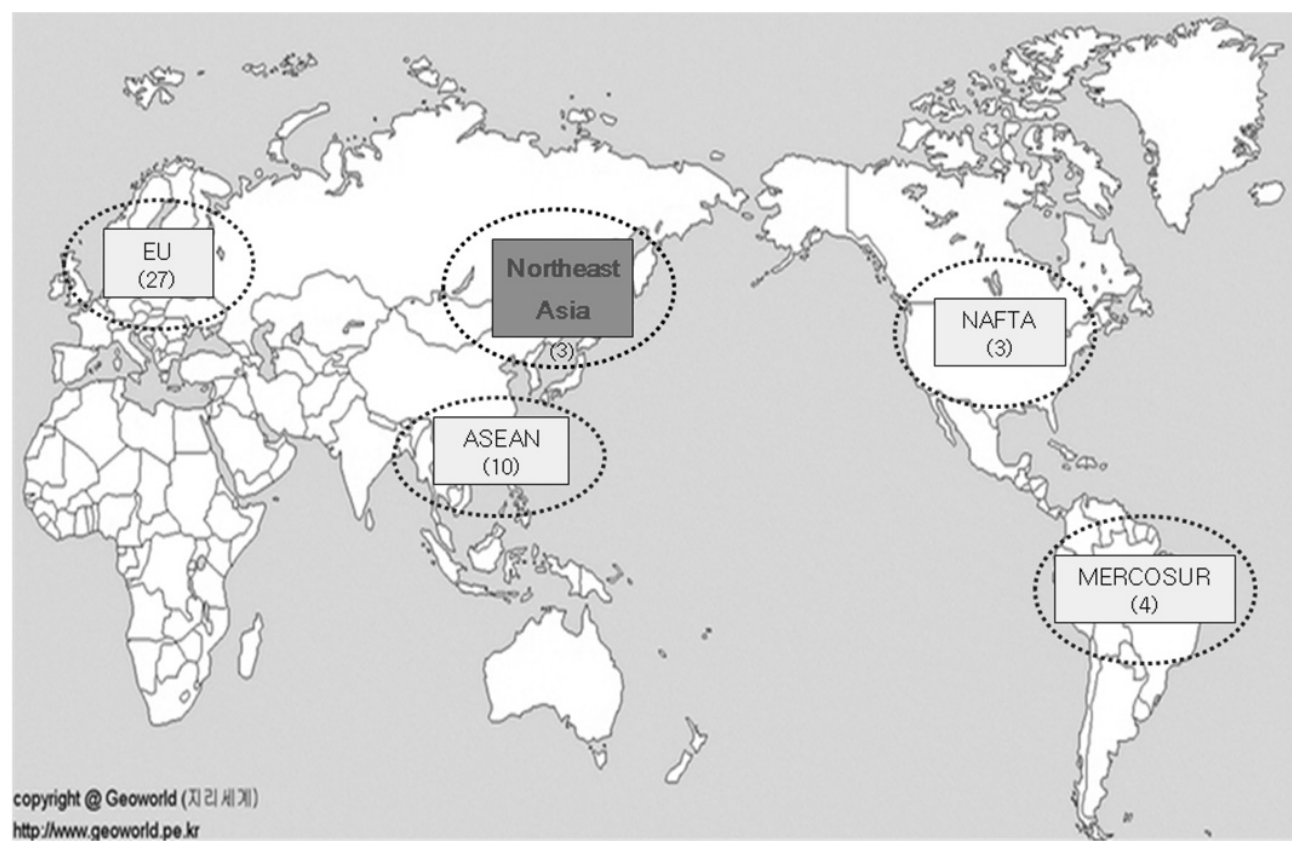

Fig. 2. Main economic blocks in the world. 


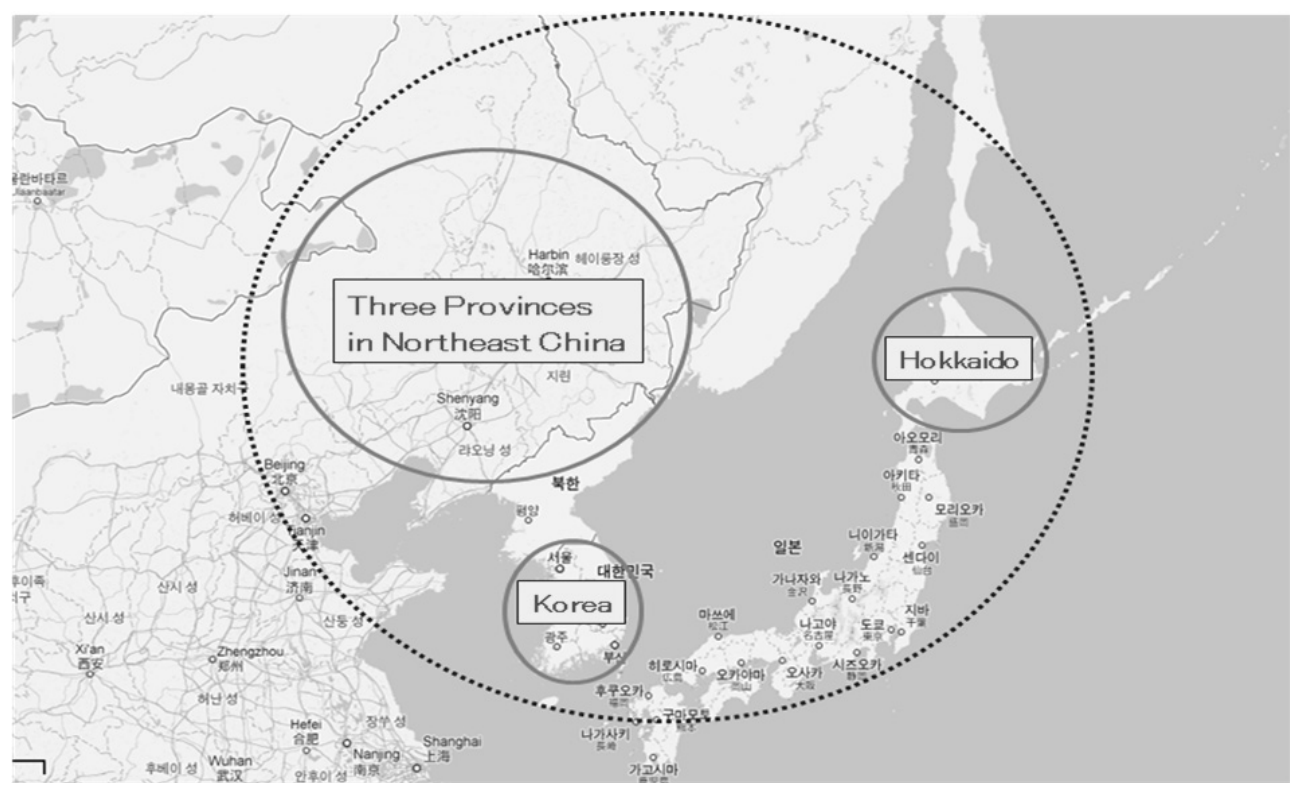

Fig. 3. Northern areas of three countries.

10 Southeastern Asian countries' ASEAN, 4 South American countries' MERCOSUR and so on. In addition, there are EFTA (4 countries), GCC (6 countries), SACU (5 countries), Central America (6 countries) and so on. Out of these, EU has the strong economic cooperation system with the operation of the common currency, Common Agricultural Policy (CAP).

In terms of the size of the economic capacity, the world economy can be explained in three axes; the North American area based on the U.S., the European area and the North-east Asia based on Korea, China, and Japan. In this aspect, North-east Asia alone does not have an official economic cooperation system. If North-east Asia centering around Korea'China Japan establishes the economic cooperation system and along with the re-unification of North and South Koreas, adopts the cooperative system with Russia, which recently joined WTO, ASEAN, Central Asia, India, Australia, etc., this area will rise as a center of the world economy.

This paper is based on the North-east Asian economic cooperation system centering on Korea·China'Japan and as shown in Figure 3, the agricultural cooperation is the focal point in Korea (North Korea after the re-unification), three north-eastern provinces of China, and Hokkaido of Japan. The characteristics of this area are that it is located in the northern part of Japan and China and the site of the agricultural production.

First of all, the size of three areas put together is $972,000 \mathrm{~km}^{2}$ (Hokkaido 83,000 + Korea 100,000 + 3 north-east provinces of China 789,000) and the population is 164,700,000 (Hokkaido 6 million + Korea 50 million + three north-east provinces of China 108.3 million). The huge population implies production capacity and big markets. Hokkaido and Heilongjiang in China are the main area of forestry and the sea around Hokkaido is full of fishery products. Above all, the three areas are geographically in proximity and have similar climates, so that agricultural cooperation has the great potential.

\section{(2) The basic structure of agriculture in Korea, China, and Japan}

The shares of agriculture in GDP in all three countries are on the decrease but compared to Korea and Japan, it is still high in China. The share of agriculture/fishery in Korea dropped from $29.1 \%$ in 
Table 1. The structure of agriculture in the three countries in 2010 .

\begin{tabular}{lccc}
\hline \multicolumn{1}{c}{ Items } & Korea & Japan & China \\
\hline Area of Agricultural Land (10,000 ha) & 172 & 459 & $12,172(09)$ \\
-Area of Agricultural Land per Household (a) & 146 & 181 & $52(05)$ \\
-Ratio of Rice Field (\%) & 57 & 54 & $26(05)$ \\
Number of Farm Household(10,000 households) & 118 & 253 & $25,223(05)$ \\
Population of Farm Household (10,000 persons) & 306 & 679 & $71,288(09)$ \\
-Ratio of the Farm Household Population (\%) & 6.4 & 5.3 & $53.4(09)$ \\
\hline
\end{tabular}

Note: Figures in parentheses of China show the year.

Source: MIFAFF (2011).

1970 to $2.6 \%$ in 2010. In Japan, the share of agriculture is less than $1 \%$ and in China, it is estimated to be around $15 \%$.

Table 1 indicates the basic structure of the three countries' agriculture. As for the cultivated acreage, Korea has 1.7 million ha, Japan has 4.6 million ha (2.7 times of Korea), and China has 121.7 million ha (70.8 times of Korea). Though the cultivated acreage per household includes the use rate of the cultivated land, all three countries have as little as 1 2 ha. For Korea and Japan, the rice field takes more than half of the cultivated acreage but for China, it takes a quarter.

From the used size of the Korean cultivated acreage, rice takes $49.0 \%$ in 2010. The next order is vegetable $11.3 \%$, fruits $8.6 \%$, special crops $4.7 \%$, beans $4.6 \%$, barleys $2.8 \%$, and potato and sweet potato 2.3\%. As the rice market is opened and the price drops, the Korean agriculture with the high dependency on rice has structural weakness.

On the other hand, the shares of crops from the Korean agricultural production value (43.5 trillion Won) in 2010 indicate the order of animal husbandry (40.2\%), vegetable (19.2\%), food crops (18.4\%) and fruit (8.2\%), and total of 4 categories is $86 \%$. The top 10 items are rice (15.6\%), pork (12.2\%), beef (10.5\%), chicken (4.9\%), milk (3.9\%), egg (3.1\%), duck (3.0\%), strawberry (2.4\%), ginseng (2.2\%), and tangerine (2.1\%). Animal husbandry takes 6 items, which implies the big shares in the total.

The numbers of farm households are 1.2 million in Korea, 2.5 million in Japan (2.1 times of Korea) and
252.2 million in China (213.8 times of Korea). The shares of part-time farm households including the self-supply are $46.7 \%$ in Korea and $82.2 \%$ in Japan. Japan has a high dependency on the part-time farming.

In addition, as for the farming population, Korea has 3.1 million, Japan has 6.8 million (2.2 times of Korea) and China has 712.4 million (232.8 times of Korea). As for the share of farming population from the total population, Korea has 6.4\%, Japan has 5.3\% and China has 53.4\%. While in Korea and Japan, the farming populations drop rapidly, in China, there are still many farming populations.

In all three countries, aging in farming areas becomes serious. In 2010, the share of farmers over 65 years old was $32 \%$, which was doubled from $16 \%$ of 1995. In the same year in Japan, the percentage of the core farmers and the farming employees who are over 65 years old reached $62 \%$. It is estimated that the aging level of the Korean agricultural workers is similar to that of the Japanese workers.

In 2010, the Korea's independence rate of food supply (including animal feed) is as low as $26.7 \%$. It is $54.9 \%$ without the feed. The Korea's independence rate of food supply has been reduced from $56.0 \%$ in 1980 to $43.1 \%$ in $1990,29.7 \%$ in 2000 and $26.7 \%$ in 2010. Around 2010, the independence rate of beef supply was $43.2 \%$ the lowest in animal husbandry. The independence rate of the meat as a whole was $72.6 \%$ and that of milk is $63.8 \%$. On the other hand, the Japan's independence rate of food supply (including animal feed) in 2010 was about $40 \%$ with the calorie 
Table 2. Trends in per capita consumption of major food in three countries.

(Unit: $\mathrm{kg}$ )

\begin{tabular}{ccccc}
\hline \multicolumn{2}{c}{ Food } & 1990 & 2000 & 2010 \\
\hline \multirow{6}{*}{ Korea } & Rice & $119.6($ Cereal 167.0$)$ & $93.6(153.3)$ & $69.8(126.0)(2011)$ \\
& Vegetables & 132.6 & 165.9 & $154.3(2011)$ \\
& Fruit & 41.8 & 58.4 & $56.8(2011)$ \\
& Meat & 19.9 & 31.9 & $41.3(2011)$ \\
& Dairy & 42.8 & 59.2 & $64.9(2010)$ \\
\hline \multirow{6}{*}{ Japan } & Rice & 70.0 & 64.6 & $64.6(2009)$ \\
& Vegetables & 107.2 & 101.5 & $105.3(2009)$ \\
& Fruit & 37.3 & 41.5 & $53.4(2009)$ \\
& Meat & 28.5 & 28.8 & $43.5(2009)$ \\
& Dairy & 83.2 & 94.2 & $84.8(2009)$ \\
\hline \multirow{6}{*}{ China } & Rice & $130.7(262.1)$ & $82.3(249.5)$ & $81.5(181.4)$ \\
& Vegetables & $138.7(134.0)$ & $114.7(112.0)$ & $116.1(93.3)$ \\
& Fruit & $41.1(5.9)$ & $57.5(18.3)$ & $54.2(19.6)$ \\
& Meat & $25.1(12.6)$ & $27.5(17.5)$ & $34.7(20.0)$ \\
& Dairy & $6.4(5.2)$ & $8.2(7.1)$ & $8.8(6.3)$ \\
\hline
\end{tabular}

Note: The numbers of China shown in urban areas, whereas numbers in the parentheses show in rural areas.

Meat in China contains beef, pork, chicken, and lamb.

Source: Korea and Japan-MIFAFF (2011), China-Jeon (2012a).

basis.

Table 2 shows the annual consumption trend of the major food per person in Korea, China and Japan. In all three countries, the consumption of all crops, especially that of rice per person has decreased. On the other hand, the consumption of meat and dairy products is on the rise, which implies that the food consumption has been sophisticated. However, the Japanese consumption of rice, vegetable and fruit per person stopped the decrease around in 2008 and gradually increased. This is thought to be related to the education on the Japanese style of eating habit and the local food consumption. On the other hand, in China, in terms of food consumption, there is a big discrepancy between urban areas and farming areas.

The vegetable consumption per person is $154.3 \mathrm{~kg}$ in Korea, higher than $116.1 \mathrm{~kg}$ in China and $105.3 \mathrm{~kg}$ in Japan. It is due to the Korean eating habit that each meal is consumed with Kimchi and side dishes and meat is consumed with leaf vegetables. Fruit consumptions in three countries are similar between 53 $\mathrm{kg}$ and $57 \mathrm{~kg}$.

For the reference, Engel's coefficients were 26.4\% in Korea in 2007 (26.9\% in 2011), 23.0\% in Japan, $36.3 \%$ in urban areas of China and $43.1 \%$ in rural areas of China. In 2011, the share of eating-out in the Korean food cost was $46.8 \%$.

\section{1) The agricultural structure of Hokkaido in Japan}

Table 3 shows the agricultural location of Hokkaido, the number one granary in Japan. The cultivated acreage of Hokkaido is as big as a quarter of the nation and specialized in land use-type agriculture such as meadow for dairying, potatoes, beans, etc. When mainland Japan excluding Hokkaido has a parttime agricultural structure, Hokkaido has high percent of full-time farming households (63\%). In 2010, the agricultural production value of Hokkaido was JPY 994.6 trillion, which took $12 \%$ of the national value and from this, animal husbandry took $52 \%$ and field husbandry took $48 \%$.

The cultivated acreage per farming household in Hokkaido is 22ha, 15 times of mainland Japan, the size per dairying household is 110.4 heads, 2.3 times of mainland Japan and the size per beef cattle household is 178.6 heads, 5.3 times of mainland Japan. In addition, 
Table 3. Overview of agriculture at Hokkaido in 2011.

\begin{tabular}{|c|c|c|c|}
\hline Items & $\begin{array}{l}\text { Hokkaido } \\
\text { (A) }\end{array}$ & $\begin{array}{l}\text { Japan } \\
\text { (B) }\end{array}$ & $\begin{array}{l}\text { Share } \\
(\mathrm{A} / \mathrm{B}) \%\end{array}$ \\
\hline Agricultural land (1,000 ha) & 1,155 & 4,561 & 25.3 \\
\hline Farm households (1,000 households) & 43 & 1,561 & 2.8 \\
\hline - Full-time farmers & 27 & 439 & 6.2 \\
\hline Farmers $(1,000$ persons $)$ & 109 & 2,601 & 4.2 \\
\hline Agricultural output in 2010 (billion yen) & 9,946 & 82,551 & 12.0 \\
\hline - Crop (billion yen) & 4,806 & 55,513 & 8.7 \\
\hline - Livestock (billion yen) & 5,139 & 26,475 & 19.4 \\
\hline Domestic supply of calorie in 2009 (kcal/man days) & 197 & 964 & 20.4 \\
\hline Items & $\begin{array}{l}\text { Hokkaido } \\
\text { (A) }\end{array}$ & $\begin{array}{l}\text { Other Prefectures } \\
\text { (b) }\end{array}$ & $\begin{array}{l}(\mathrm{a} / \mathrm{b}) \\
\text { (times) }\end{array}$ \\
\hline Farm size (ha) & 22.0 & 1.5 & 14.7 \\
\hline Ratio of farmers under the age of $65(\%)$ & 69.8 & 39.3 & 1.9 \\
\hline Ratio of full-time farmers (\%) & 72.1 & 21.4 & 3.4 \\
\hline Size of dairy cattle farms (head) & 110.4 & 47.4 & 2.3 \\
\hline Size of beef cattle farms (head) & 178.6 & 33.4 & 5.3 \\
\hline Farm income in 2010 (1,000 yen) & 6,026 & 1,080 & 6.5 \\
\hline Off-farm income in 2010 ( 1,000 yen $)$ & 676 & 1,638 & 0.4 \\
\hline Weight of agriculture in $2010(\%)$ & 90.1 & 39.6 & 2.3 \\
\hline
\end{tabular}

Note: 1) Full-time farmers are under the age of 65 mainly in farm income, and they are engaged in agriculture for more than 60 days per year.

2) Degree of agricultural dependence $=$ farm income/total income.

Total income $=$ farm income + income related to agricultural production + non-farm income

Source: Hokkaido Prefecture (2012).

the core farmers in Hokkaido who are below 65 years old are $69.8 \%$, which is much higher than $39.3 \%$ of mainland Japan. This indicates that it has better agricultural conditions for high productivity.

The percentages of production volumes of Hokkaido's main items against the national volumes as of 2010 or 2011 are as follows; wheat $67 \%$, bean $27 \%$, adzuki bean $90 \%$, kidney bean $94 \%$, buck wheat $37 \%$, corn for feed $46 \%$, and potato $79 \%$ from food crops, onion 55\%, carrot 28\%, zucchini 48\%, Japanese yam 47\%, and sugarcane $100 \%$ from vegetable, beef $16 \%$, milk 51\%, and light racing horse $97 \%$ from animal husbandry.

\section{2) The agricultural structure of three north-eastern provinces in China}

Table 4 and Table 5 show the summary of agriculture in three north-eastern provinces of China between 2008 and 2011. The total acreage for cultivation of three provinces is 2.1 million ha, $17.6 \%$ of the nation.
In particular, Heilongjiang province has 1.2 million ha, $55 \%$ of the total three provinces. The utilization status of the cultivated acreage of three provinces shows the order of corn in 8.4 million ha, corn in 5.14 million ha, rice in 3.71 million ha, vegetable in 0.89 million ha, and fruit in 0.43 million ha. The agricultural population is 58.7 million from whom 27.2 million live in Liaoning Province, $46 \%$ of the population of total three provinces. The composition of the agricultural population is Liaoning Province 64\%, Jilin Province $54 \%$ and Heilongjiang Province 44\%.

The volume of food production is 89.3 million tons, $16.9 \%$ of the national volume. Major crops are rice, corn and bean and in terms of the production volume, rice takes $13.6 \%$, corn $30.7 \%$ and bean $40.4 \%$. This area is also the home of animal husbandry such as beef cattle, dairying (Heilongjiang province), pig, sheep, chicken, etc. In terms of agricultural output, the national share of animal husbandry is $12.8 \%$, higher 
Table 4. Overview of three northeast provinces in China in 2010/2011.

\begin{tabular}{|c|c|c|c|c|}
\hline Items & $\begin{array}{c}\text { Jilin } \\
\text { Province }\end{array}$ & $\begin{array}{l}\text { Liaoning } \\
\text { Province }\end{array}$ & $\begin{array}{l}\text { Heilongiiang } \\
\text { Province }\end{array}$ & Total \\
\hline -Area $\left(1,000 \mathrm{~km}^{2}\right)$ & 18.7 & 14.8 & 45.4 & 78.9 \\
\hline -Population (million persons) & 2,724 & 4,272 & 3,834 & 10,830 \\
\hline ·Farmers (million persons) & 1,481 & 2,719 & 1,668 & 5,868 \\
\hline Share of farmers $(\%)$ & 54.4 & 63.9 & 43.5 & - \\
\hline -Share of employees by industry $1,2,3(\%)$ & $43: 20: 37$ & $30: 28: 42$ & $41: 20: 39$ & - \\
\hline -GDP (billion Yuan) & 10,531 & 22,026 & 12,504 & 45,061 \\
\hline ·Per capita GDP (Yuan) & 38,321 & 50,299 & 32,613 & - \\
\hline -Total trade amount (billion dollars) & 221 & 959 & 385 & 1,565 \\
\hline Exports (billion dollars) & 50 & 510 & 177 & 737 \\
\hline -Imports (billion dollars) & 171 & 449 & 208 & 828 \\
\hline -Per capita farm income (Yuan) & 7,510 & 8,297 & 7,591 & - \\
\hline -Revenue from foreign tourists (million dollars) & 3.9 & 27.1 & 9.2 & 40.2 \\
\hline Foreign tourists $(1,000$ persons $)$ & 85.5 & 410.3 & 206.5 & 702.3 \\
\hline
\end{tabular}

Source: JETRO (2012).

Table 5. Key indicators of agriculture at the three northeast provinces in China in 2008.

\begin{tabular}{|c|c|c|c|c|c|c|}
\hline \multirow{2}{*}{ Indicators } & \multicolumn{3}{|c|}{ Three provinces } & \multirow{2}{*}{$\begin{array}{l}\text { Total } \\
\text { (A) }\end{array}$} & \multirow{2}{*}{$\begin{array}{l}\text { China } \\
\text { (B) }\end{array}$} & \multirow{2}{*}{$\begin{array}{l}\text { Share } \\
(\mathrm{A} / \mathrm{B})\end{array}$} \\
\hline & Jilin & Liaoning & Heilongjiang & & & \\
\hline Agricultural land (1,000 ha) & 553 & 409 & 1,183 & 2,145 & 12,172 & $17.6 \%$ \\
\hline -Rice & 66 & 66 & 239 & 371 & 2,924 & 12.7 \\
\hline -Corn & 292 & 189 & 359 & 840 & 2,986 & 28.1 \\
\hline -Soybean & 62 & 20 & 432 & 514 & 1,212 & 42.5 \\
\hline -Vegetables & 21 & 39 & 29 & 89 & 1,788 & 5.0 \\
\hline -Fruits & 6 & 33 & 4 & 43 & 1,073 & 4.0 \\
\hline $\begin{array}{l}\text { Employees in the } 1 \text { stindustry } \\
\text { (million persons) }\end{array}$ & 511 & 698 & 776 & 1,985 & 28,863 & 6.9 \\
\hline $\begin{array}{l}\text { The amount of chemical fertilizer used } \\
\text { (million tons) }\end{array}$ & 164 & 129 & 181 & 474 & 5,239 & 9.0 \\
\hline Ag. production (billion Yuan) & 1,615 & 2,477 & 2,123 & 6,215 & 58,002 & 10.7 \\
\hline -Crop & 749 & 897 & 1,142 & 2,788 & 28,044 & 9.9 \\
\hline -Livestock & 770 & 1,052 & 813 & 2,635 & 20,584 & 12.8 \\
\hline Food production (million tons) & 2,840 & 1,860 & 4,225 & 8,925 & 52,871 & 16.9 \\
\hline -Cereal & 2,705 & 1,760 & 3,502 & 7,967 & 47,847 & 16.6 \\
\hline -Rice & 579 & 506 & 1,518 & 2,603 & 19,190 & 13.6 \\
\hline Corn & 2,083 & 1,189 & 1,822 & 5,094 & 16,591 & 30.7 \\
\hline -Soybean & 107 & 53 & 667 & 826 & 2,043 & 40.4 \\
\hline -Fruits & 274 & 592 & 368 & 1,233 & 19,220 & 6.4 \\
\hline Land productivity (Yuan/ha) & 29,176 & 60,631 & 17,949 & 35,919 & 47,654 & - \\
\hline Labor productivity (Yuan/person) & 31,603 & 35,476 & 27,378 & 31,486 & 20,096 & - \\
\hline Farmer's per capita income (Yuan) & 4,933 & 5,576 & 4,856 & 5,122 & 4,761 & - \\
\hline $\begin{array}{l}\text { Income gap between rural area and urban } \\
\text { area (times) }\end{array}$ & $2.6: 1$ & 2.6:1 & 2.4:1 & $2.5: 1$ & $3.3: 1$ & - \\
\hline Agricultural exports (billion dollars) & 1.1 & 3.4 & 0.9 & 5.4 & 40.2 & 13.4 \\
\hline
\end{tabular}

Source: Jeon et al. (2009).

than $9.9 \%$ of cultivation. In 2010, the annual average income per farmer was 8,297 Yuan in Liaoning province, 7,591 Yuan in Heilongjiang province and 7,510 Yuan in Jilin province.
The productivity of land in three provinces was 35,919 Yuan per person in 2008, 75\% higher than the national average of 47,654 Yuan. However, the labor productivity was 31,486 Yuan per person, 57\% higher 
than the national average of 20,096 Yuan. The produce export from three provinces was 5.4 billion dollars in 2008, 13.4\% of the national export. The produce export value of Liaoning province was 3.4 billion dollars, $63 \%$ of the total three provinces. The income discrepancy between cities and farming areas was that the average for three provinces was 2.5:1, lower than the national average of $3.3: 1$.

\section{The structure of agricultural trade in Korea, China, and Japan}

\section{(1) Trends of export and import of agricultural products}

\section{1) Trends of import and export of agricultural products in three countries}

Table 6 shows the trends in import and export of agricultural products in Korea, China, and Japan. In 2010, Chinese produce export value was 38.3 billion dollars, much higher than 4.1 billion dollars of Korea and 3.2 billion dollars of Japan. The increase rate of produce export from 2000 to 2010 was 208\% for China, higher than $173 \%$ for Korea and $88 \%$ for Japan.

The review of the import value of the produce from three countries in 2010 shows that Japan spent 62.8 million dollars, China spent 56.7 million dollars and Korea spent 22.4 million dollars. In terms of the increase rate of produce import, between 2000 and 2010, China showed the rapid increase of $786 \%$, Korea with $164 \%$ and Japan with 78\%. The trade balance of 2010 shows that Japan has minus 59.6 million dollars, bigger than Korea with minus 18.3 million dollars and China with minus 17.9 million dollars.

For a long time, China stayed as a surplus country in produce trade but since the later 2000s, it fell to a deficit country. Between 2000 and 2010, the difference of the trade balance deficit was 26 billion dollars for Japan and 11.3 billion dollars for Korea. During this time, China turned from surplus to deficit and the worth of 24.1 billion dollars of trade balance was aggravated.

At this point, the fact that all three countries are deficit countries in the produce trade balance shows that the anxiety toward the food security in general gets bigger. Though Japan is a big import country in produce but recently the increase is not significant. Over this shrinking Japanese import market for produce, the competition for export between China and Korea will be more serious.

Table 6. Trends of import and export of agricultural products in Korea, Japan, and China.

(Unit: billion dollars)

\begin{tabular}{cccccc}
\hline Country & Item & 2000 & 2005 & 2010 & $2010 / 2000(\%)$ \\
\hline \multirow{4}{*}{ Korea } & Export (A) & 15 & 22 & 41 & 273.3 \\
& Import (B) & 85 & 119 & 224 & 263.5 \\
\cline { 2 - 6 } & Balance of trade (A-B) & -70 & -97 & -183 & -113 (difference) \\
\cline { 2 - 5 } Japan & Export (A) & 17 & 21 & 32 & 188.2 \\
& Import (B) & 353 & 543 & 628 & 177.9 \\
\cline { 2 - 6 } & Balance of trade (A-B) & -336 & -522 & -596 & -260 (difference) \\
\hline \multirow{3}{*}{ China } & Export (A) & 126 & 221 & 388 & 307.9 \\
& Import (B) & 64 & 193 & 567 & -241 (difference) \\
\cline { 2 - 5 } & Balance of trade (A-B) & 62 & 28 & 465.9 \\
\hline \multirow{3}{*}{ Total } & Export (A) & 158 & 264 & 1,419 & 291.8 \\
& Import (B) & 502 & 855 & -958 & -614 (difference) \\
\cline { 2 - 5 } & Balance of trade (A-B) & -344 & -591 & & 282.7 \\
\hline
\end{tabular}

Note: Figures include forest products, but exclude fishery products.

Sources: Korea- MIFAFF (2011), Japan-MAFF (2012). 


\section{2) The situation of Korean agricultural trade with} Japan and China

Table 7 shows the status of Korean trade product to Japan and China. First, the Korean trade of produce to Japan will be reviewed. In 2010, the Korea's export of agricultural/livestock products to Japan was 1.02 billion dollars, 2.4 times more than the import of 0.43 billion dollars and the surplus trade balance was 0.59 billion dollars. However, between 2005 and 2010, the export increased by $43 \%$ but the import increased by $116 \%$. During this period, the surplus trade balance of Korea to Japan increased by $15.1 \%$.

Korea's main export items to Japan were paprika, cucumber, eggplant, strawberry, lily, Kimchi, etc. and the import items were seed, green tea, processed food for functions, materials for controlled horticulture, etc. As shown in Table 8, the only produce included in top 10 export items to Japan (including fishery products) in 2011 was paprika ranked $8^{\text {th }}$ and as processed food, Kimchi was ranked no. 6. Vegetable seed was ranked no. 6 as the import item from Japan.

Next, the Korea's produce trade with China is looked into. The produce trade between Korea and China has been increased since the diplomatic relation in 1992. In 2010, Korea's trade value of agricultural/ fishery products to China was 0.56 billion dollars for export and 3.23 billion dollars for import with the deficit trade balance of 2.67 billion dollars. It was unbalanced since Korea's import of product to China was 5.8 times of the export. From 2005 to 2010, the export increased by $141 \%$ and the import increased by $46 \%$. During this period, the deficit trade balance to China increased by $34.6 \%$.

Table 8 shows the main produces to export to China in 2011 and sucrose was ranked no. 2 and red ginseng ranked no. 7. As for import items, rice for MMA was ranked no. 1, starch pulp no.5, pepper no. 6, Kimchi no. 8, garlic no. 9 and other vegetables no. 10. China secured an export base in proximity to Korea such as Shandong province and seeks to increase the export to Korea and Japan with a strong export system in a collective form such as Export Corporation. Recently, China reinforces the food security system of Shandong province and pays a great attention on the safety

Table 7. Current situation of Korean agricultural trade with Japan and China.

(Unit : million dollars)

\begin{tabular}{|c|c|c|c|c|c|}
\hline Country & & Items & 2005 & 2010 & $2010 / 2005$ \\
\hline \multirow{9}{*}{ To Japan } & \multirow{4}{*}{ Export } & -Total (A) & 713.3 & $1,023.1$ & 143.4 \\
\hline & & -Agricultural products & 620.5 & 967.4 & 155.9 \\
\hline & & Livestock products & 39.0 & 24.6 & 63.6 \\
\hline & & -Forest products & 53.8 & 31.1 & 57.8 \\
\hline & \multirow{4}{*}{ Import } & -Total (B) & 200.1 & 432.6 & 216.2 \\
\hline & & -Agricultural products & 144.7 & 343.6 & 237.5 \\
\hline & & -Livestock products & 48.4 & 14.2 & 29.3 \\
\hline & & $\cdot$ Forest products & 7.0 & 74.8 & $1,068.6$ \\
\hline & \multicolumn{2}{|c|}{ Balance of trade (A-B) } & 513.2 & 590.5 & 115.1 \\
\hline \multirow{9}{*}{ To China } & \multirow{4}{*}{ Export } & -Total（A） & 231.2 & 556.2 & 240.6 \\
\hline & & -Agricultural products & 184.5 & 446.6 & 242.1 \\
\hline & & Livestock products & 6.2 & 23.4 & 377.4 \\
\hline & & -Forest products & 40.5 & 86.2 & 212.8 \\
\hline & \multirow{4}{*}{ Import } & -Total (B) & $2,216.5$ & $3,227.5$ & 145.6 \\
\hline & & -Agricultural products & $1,757.0$ & $1,945.7$ & 110.7 \\
\hline & & -Livestock products & 71.2 & 53.3 & 74.9 \\
\hline & & Forest products & 388.3 & $1,228.5$ & 316.4 \\
\hline & \multicolumn{2}{|c|}{ Balance of trade (A-B) } & $-1,985.3$ & $-2,671.3$ & 134.6 \\
\hline
\end{tabular}

Sources: MIFAFF (2006, 2011). 
Table 8. Main agricultural trade items of Korea with Japan and China in 2011.

(Units : million dollars, \%)

\begin{tabular}{|c|c|c|c|c|c|c|c|c|}
\hline \multirow{3}{*}{$\begin{array}{c}\text { Rank } \\
1\end{array}$} & \multicolumn{4}{|c|}{ To Japan } & \multicolumn{4}{|c|}{ To China } \\
\hline & \multicolumn{2}{|c|}{ Export amount } & \multicolumn{2}{|c|}{ Import amount } & \multicolumn{2}{|c|}{ Export amount } & \multicolumn{2}{|c|}{ Import amount } \\
\hline & Other fishes & 199 & Mixed foods & 94 & Mixed foods & 236 & Rice & 230 \\
\hline 2 & $\underline{\text { Tuna }}$ & 177 & Pulp & 38 & Sucrose & 143 & Plywood & 216 \\
\hline 3 & Mixed foods & 160 & Bream & 29 & Cuttlefish & 100 & Octopus & 186 \\
\hline 4 & Fermented liquors & 138 & Pollack & 29 & Coffee goods & 51 & Mixed foods & 185 \\
\hline 5 & Liquor & 93 & Shortening & 26 & $\underline{\text { Codfish }}$ & 47 & Starch dregs & 169 \\
\hline 6 & Kimchi & 87 & Vegetable seeds & 20 & $\overline{\text { Fish eggs }}$ & 40 & Red pepper & 162 \\
\hline 7 & Sugar candies & 80 & Mackerel & 19 & Red ginseng & 39 & Yellow corvine & 162 \\
\hline 8 & Paprika & 66 & Beer & 18 & Soybean oil & 33 & Kimchi & 121 \\
\hline 9 & Laver & 58 & Other fishes & 18 & Spanish mackerel & 32 & Garlic & 95 \\
\hline 10 & Cup noodle & 53 & Sauce products & 17 & Pollack & 31 & Other Vegetables & 85 \\
\hline
\end{tabular}

Note: Items underlined are fishery products.

Sources: MIFAFF (2012, unpublished material).

Table 9. Trends in the agricultural trade of Korea with China.

\begin{tabular}{|c|c|c|}
\hline Items & Trends in import & Trends in export \\
\hline Food crops & $\begin{array}{l}\text {-Share of China in the trade of food crops } \\
\text { in Korea is decreasing. } 36.3 \rightarrow 7.6 \% \\
\text {-Corn import decreased sharply. } \\
\text {-Imports of rice and soybeans are increasing }\end{array}$ & $\begin{array}{l}\text {-Share of food crops export to China is very small: } \\
\text { less than } 1 \% \\
\text {-Wheat goods are main items : } 79 \%\end{array}$ \\
\hline Vegetables & $\begin{array}{l}\text {-Share of China in the trade of vegetables } \\
\text { in Korea is increasing } 3.6 \rightarrow 21.7 \% \\
\text { Kimchi, red pepper, garlic, leek, onion }\end{array}$ & $\begin{array}{l}\text {-Share of vegetables exports to China is also very } \\
\text { small : } 2 \% \\
\text {-Vegetable seeds : } 50.2 \%\end{array}$ \\
\hline Fruits & $\begin{array}{l}\text {-Import of fruit processed products from } \\
\text { China increased slightly. } 0.7 \rightarrow 3.0 \% \\
\text {-Chinesefreshfruitsarenotimportedbecause } \\
\text { of quarantine problem. } \\
\text {-Fruit processed products are dominant. }\end{array}$ & $\begin{array}{l}\text {-Export of fruit processed products to China increased: } \\
0.4 \rightarrow 6.0 \% \\
\text {-Main item is citron processed tea. } 48.6 \%\end{array}$ \\
\hline $\begin{array}{l}\text { Livestock } \\
\text { products }\end{array}$ & $\begin{array}{l}\text {-Share of Chinese livestock products imported } \\
\text { is about } 3 \% \\
\text {-Weight of meat particularly poultry products } \\
\text { increased: } 19.7 \rightarrow 51.7 \% \text { (poultry } 35.2 \% \text { ) } \\
\text {-Fresh meats are not imported from China } \\
\text { because of quarantine problem. } \\
\text {-Main items are heat-treated poultry products. }\end{array}$ & $\begin{array}{l}\text {-Share of livestock products in agricultural exports to } \\
\text { China increased: } 1.0 \rightarrow 5.0 \% \\
\text {-Main export items are dairy products: milk powder } \\
\text { for children }(27.6 \%) \text {, skim milk }(20.2 \%)\end{array}$ \\
\hline $\begin{array}{l}\text { Processed } \\
\text { agricultural } \\
\text { products }\end{array}$ & $\begin{array}{l}\text {-Share of processed agricultural products } \\
\text { imported from China increased largely : } \\
28.6 \rightarrow 54.3 \% \\
\text {-Main import items from China : dregs of } \\
\text { starch and soybean, vegetable seeds for oil. }\end{array}$ & $\begin{array}{l}\text {-Share of processed agricultural products exported to } \\
\text { China decreased slightly. } 96.2 \rightarrow 86.6 \% \\
\text {-Main exports items to China : sucrose, cup noodle, } \\
\text { cookies, coffee goods, ginseng, beverages, liquor, } \\
\text { sauce, tobacco }\end{array}$ \\
\hline
\end{tabular}

Note: The comparison period is between the average from 1992 to 1994, and that from 2008 to 2010.

Source: Jeon (2012b).

management of the export produces. In addition, they export produces with the light processing such as freezing, drying, marinated storage, etc. at the low tariff or make efforts to develop new export items (e.g. potato starch, chestnut, leaf tobacco, etc.).
Table 9 shows the summary of the trade trend per produce item between Korea and China during 1992 - 1994 (average) and 2008 - 2010 (average). Looking at it in a big picture, the import of food crops from China has decreased and instead, the import of 
vegetables and processed produce has increased. The cause of the decrease of import of food crops was the sharp decrease of import of corns which used to be the biggest import item. However, the import of rice for MMA, beans for bean-sprout, and adzuki beans has increased significantly.

As for the import of vegetables, Kimchi, pepper, garlic, carrot, tomato, green onion, onion, etc. take the big share and the vegetables for seasoning are the main items. As for processed produce, the biggest import items are pulps and sesames. As for pulps, starch pulp, soybean meal, sugar pulp, and brewing pulp are the main items and as for oil peanuts, sesame seeds, and perilla seeds are the main items. In addition, the rest of items with big import values are formula feed, sauces (mixed seasoning, soybean paste, etc.), glucose, glass noodle, and processed forest products (lumber, plywood, and single board).

The main export items to China are flour (mixed form), vegetable seeds, citron tea (processed fruit products), dairy products (milk powder and skim milk powder), processed produces (sugar, noodle, cookie, coffee, sauce, beverage, alcohol, ginseng, and tobacco leaf), etc. The export items in big values identified from the average of three years from 2008 to 2010 are sucrose, instant noodle, prepared coffee, compound prepared food, orchid, citron, tobacco, compound seasoning, soybean, biscuit, mushroom, red ginseng, white liquor, modified milk powder, skim milk powder, chocolate, vegetable seed, glucose, etc.

\section{(2) The intra-regional trade of agricultural products among the three countries}

Table 10 shows the regional-trade status of produce among three countries of Korea, China and Japan. As the produce export of Korea, China and Japan increased, the value of regional export increased from USD 9.8 billion in 2000 to over USD 17 billion including fishery products in 2010. However, the share of regional export in the total produce export value of three countries lowered from $59.6 \%$ to $15.3 \%$.

The regional-export value of Korean produce increased from USD 0.84 billion to USD 2.67 billion but as the regional-export increased, the share of regional-export dropped from $54.7 \%$ to $45.4 \%$. In Japan, the regionalexport of produce increased from USD 0.38 billion to USD 1.16 billion but the share of the regional-export dropped from $25.0 \%$ to $22.0 \%$. As the same for China, the regional-export value of produce increased from USD 8.57 billion to USD 13.39 billion but the external

Table 10. Current status of intra-regional agricultural trade among the three countries in 2010 . (Units : million dollars, \%)

\begin{tabular}{|c|c|c|c|c|c|c|c|c|}
\hline \multirow{2}{*}{$\begin{array}{l}\text { Exporter } \\
\text { Importer }\end{array}$} & \multicolumn{2}{|c|}{ Korea } & \multicolumn{2}{|c|}{ Japan } & \multicolumn{2}{|c|}{ China } & \multicolumn{2}{|c|}{ Total imports } \\
\hline & 2000 & 2010 & 2000 & 2010 & 2000 & 2010 & 2000 & 2010 \\
\hline Korea & & & $\begin{array}{l}219 \\
(2.6)\end{array}$ & $\begin{array}{c}659 \\
(2.6)\end{array}$ & $\begin{array}{l}1,405 \\
(16.6)\end{array}$ & $\begin{array}{l}4,323 \\
(16.8)\end{array}$ & $\begin{array}{l}1,624 \\
(19.2)\end{array}$ & $\begin{array}{l}4,982 \\
(19.3)\end{array}$ \\
\hline Japan & $\begin{array}{l}720 \\
(1.6) \\
\end{array}$ & $\begin{array}{c}1,883 \\
(2.5)\end{array}$ & & & $\begin{array}{l}7,162 \\
(11.9)\end{array}$ & $\begin{array}{l}9,066 \\
(12.7)\end{array}$ & $\begin{array}{l}7,882 \\
(17.5)\end{array}$ & $\begin{array}{l}10,950 \\
(15.2)\end{array}$ \\
\hline China & $\begin{array}{c}118 \\
(1.1) \\
\end{array}$ & $\begin{array}{c}787 \\
(1.1) \\
\end{array}$ & $\begin{array}{c}165 \\
(1.6) \\
\end{array}$ & $\begin{array}{l}497 \\
(0.7) \\
\end{array}$ & & & $\begin{array}{l}283 \\
(2.7) \\
\end{array}$ & $\begin{array}{c}1,285 \\
(1.8) \\
\end{array}$ \\
\hline Total exports & $\begin{array}{c}838 \\
(54.7)\end{array}$ & $\begin{array}{l}2,670 \\
(45.4)\end{array}$ & $\begin{array}{c}384 \\
(25.0)\end{array}$ & $\begin{array}{l}1,156 \\
(22.0)\end{array}$ & $\begin{array}{l}8,567 \\
(64.2)\end{array}$ & $\begin{array}{c}13,390 \\
(27.3)\end{array}$ & $\begin{array}{c}9,789 \\
(59.6 / 15.3)\end{array}$ & $\begin{array}{c}17,216 \\
(28.7 / 9.9)\end{array}$ \\
\hline
\end{tabular}

Note: 1) Figures in the parentheses show the share of intra-regional import. But, figures in the parentheses of total exports show the share of intra-regional export.

2) Figures in the parentheses shaped ( / ) show the total share of intra-regional export and import.

3) Figures of export and import between Japan and China are the data of 2009. Those were calculated by the exchange rate at the end of year. (1 dollar=93.6 Japanese yen).

Sources: Update of Lee and Eor (2012). 
export increased more and thus, the share of regionalexport dropped from $64.2 \%$ to $27.3 \%$.

Since Korea and China had high dependency of export on the Japanese market, the share of the regional-export was comparatively lower, but due to the increase of the external export, the share of regional-export dropped.

The regional-import value of produce among Korea, China and Japan increased but the external import increased faster, so that the share of regional-import decreased. The share of regional-import of produce among three countries decreased from 15.3\% in 2000 to $9.9 \%$ in 2010 . It was caused by the decrease of the share of Japan's regional-import which used to be the highest import value of produce.

Since Korea and Japan had high dependency of import of produce on China, the share of regionalimport was high and continued to increase. The Korea's regional-import value of produce increased from USD 1.62 billion in 2000 to USD 5 billion including fishery products in 2010 and the shares of regional-import were similar from $19.2 \%$ to $19.3 \%$. During the same period, Japan's regional-import value increased from USD 7.88 billion to USD 10.95 billion but the external import increased more and the share of the regionalimport decreased from $17.5 \%$ to $15.2 \%$. Due to Chinese low dependency of import on Korea and Japan, its regional-import value of produce and the share of import are very low.

From the perspective of 2010, the market shares of the Korean produce in the import market of Japan and the Japanese products in the import market of Korea are as low as 2 3\%. The market share of Korean products in the import market of China is less than $2 \%$. However, the Chinese products in the Korean import market is over 20\%, which is huge.

While Korea's export of produce to China does not include fresh products, the import items from China are mostly composed of fresh produce. Therefore, two countries' produce trade structure seems to be complementary to each other. However, the processed produces from China to Korea have more various items and higher values than those from Korea to China. Therefore, similar to the case of fresh products, there are one-sided and imbalanced structural problems. While China increases the export of processed produce as well as fresh produce and exclusively occupies the Korean market literally, there are few items that Korea can respond to this and make specialized.

Furthermore, though China's share of Japanese produce import market is around 15\%, Japan's share of Chinese produce import market is less than $2 \%$. As the same as in Korea, compared to the advance of Japanese produce to Chinese market, the export of Chinese produce to Japan increases tremendously, and the imbalance of the produce trade between Japan and China continues to extend.

As shown above, the regional-trade of produce among three countries of Korea, China and Japan is structurally difficult to be balanced. Especially for Korea, the import shares both from China and Japan are on the increase, but the shares of regional-export are on the decrease. Thus, the imbalance of the regional-trade of the produce becomes bigger.

\section{Directions of agriculture cooperation in Northeast Asia}

\section{(1) Necessities of agricultural cooperation in Northeast Asia}

When the agricultural structures of the three countries of Korea, China and Japan are reviewed in terms of the input of a factor, there are differences as well as similarities at the same time and thus, the necessity for the agricultural cooperation within the area is significantly high. First, the total size of the cultivated acreage varies among three countries but the average cultivated size per farming household, which is a basic unit of agricultural production, is very small and this small-sized farming is a common structural 
feature. However, the blessed rate of agricultural capital varies significantly among the countries and the fixed capital and ratio of capital/labor per Chinese household is considerably lower than those of Korea and Japan.

The agricultural structure of three countries has a common feature of the land-saving farming type but the ratio of capital/labor and that of capital/land are highest from the order of Japan, Korea and China and the ratio of labor/land is highest from the order of China, Korea and Japan. Therefore, Japan and Korea have advantages in the labor-saving and capital-using production of produce and China has an advantage in labor-using and capital-saving production of produce. Especially, Japan has more labor-saving and capital/ land-using agricultural structure than Korea.

It is necessary to search for solutions that three countries can share the markets through the establishment of a system to use more complementary production factors than the exclusive occupation of markets through unlimited competition. Price competition according to the law of comparative advantage is based on specialization of production but as the factor endowment rate changes depending on the economic growth, the gains of trade become extinct and the competitiveness becomes lost.
In terms of labor productivity, the order of Japan, Korea and China is from the highest to the lowest. Labor productivity depends on the level of establishment of infrastructure such as mechanization and automation of facilities and the technical level of farmers. Three countries try to increase the productivity and profits through the investment in agriculture and the technology cooperation.

\section{(2) Possibility and directions of agriculture cooperation in North-east Asia}

Agricultural products of three countries can be categorized into mutually competing items and complementary items. First, the mutually competing items are produced by all three countries and through the regional-trade, the prices and qualities are competed. The representative items are rice, vegetables, and fruits.

However, the mutually complementary items are the items that one country cannot produce enough or has to stop the production of and other countries produce and supply. The representative items are corns, crops, and oils.

As shown in Figure 3, the cooperation solutions in production/trade of produce can be implemented through the division of labor in the industry, regional

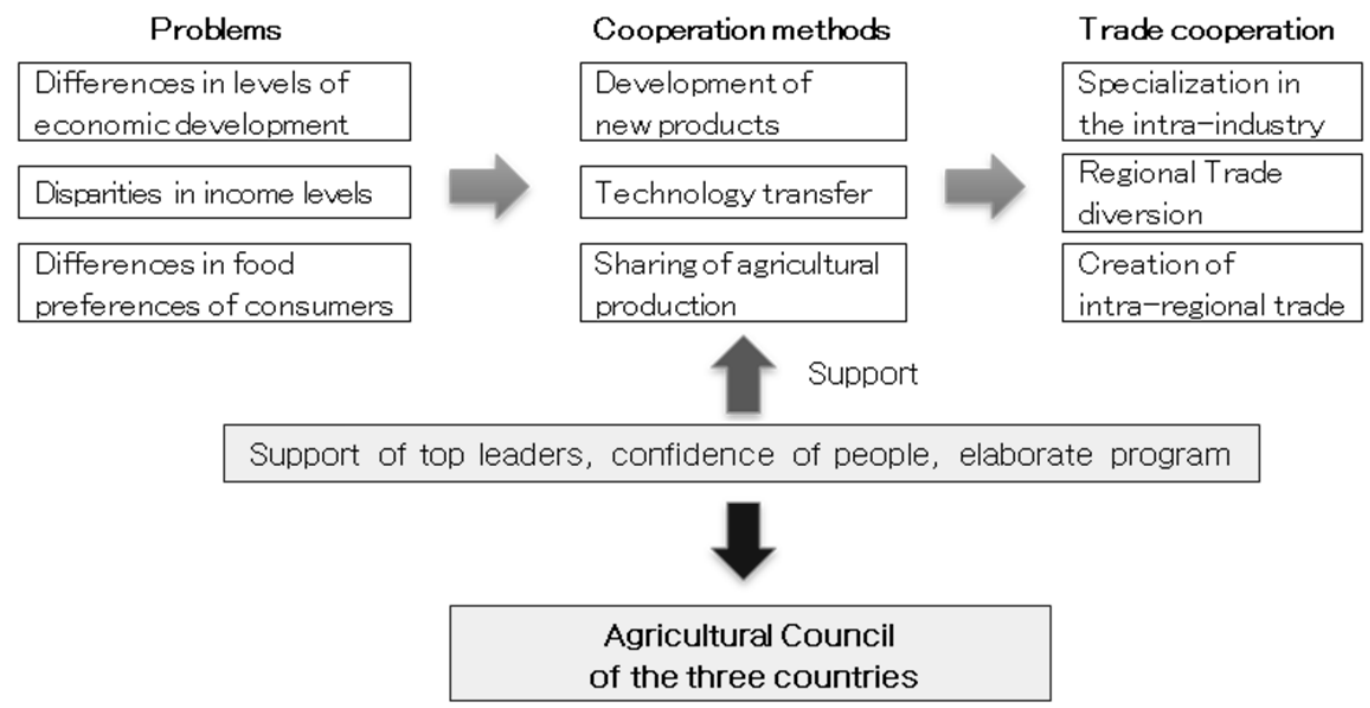

Fig. 3. The structure of agricultural cooperation in Northeast Asia. 
trade diversion and the creation of regional trade. While three countries maintain the production of competing items in each country at a certain level, the regional agricultural cooperation can be considered by internalizing the trade of the complementary items.

For example, Korea and Japan maintain the selfsufficiency rate of competing items such as rice, vegetables and fruits at a certain level but the import of the complementary items such as corns and crops can be diverted to China, which is a regional country.

Three countries already have high dependence on the regional market of produce trade. The geographical proximity to Japan, the world's largest produce import country, can be used and the advance to China with the world's largest population is comparatively advantageous.

However, the export competition of produces in Korea and Japan is significantly intense and the number of competing items between Korea and China is on the increase. In the regional sector for agriculture, instead of work-division, export competition with similar items is executed intensely.

The trade in the industry of the regional agricultural area is performed in the limited areas such as processed produces between Korea and Japan and Korea and China and the trade in the industry of fresh produce occurs rarely. However, because the export similarity index of produce implying the country's export competitiveness is high, in return, in the future, it is likely to have active division of labor in the industry of the agriculture in the countries.

Especially, three countries vary in terms of the stage of economic development, income level, preference of food as well as agricultural technology level. Therefore, for the target of each country's market in the region, if a preferable division of labor system is established in the industry through the diversified agricultural cooperation such as continuous development of new products, technology transfer, divided production of each produce item, it is predicted to create and divert the regional produce trade in the fresh produce area as well as in the processed produce area.

However, this regional agricultural cooperation cannot be achieved solely with the power of market or with the economic theories. The leader's willingness, people's understanding, elaborate programs, and so on are important factors. First, three governments should compose a consultative entity in relation to agriculture and further build a cooperation system to adjust policies and to proceed. Based on this cooperation, FTA among Korea, China and Japan or an agricultural entity for cooperation in the Northeast Asia can be made.

\section{1) Unified standards for quality and safety of agricultural food}

In order to activate the regional trade among three countries, the perquisite task is to unify the standards for quality and safety of agricultural food. If unified standards exist for major tradable items and the goods satisfying these standards are accepted equally in any countries, the regional trade of agricultural food will be more active. If possible, the standards should be as high as global standards to have the goods circulated all around the world. If this system is settled, the regional goods will be preferable to the goods from outside the three countries in the competition. As for safety, the common standards should be required on GAP, HACCP and traceability.

2) Establishment of cooperation systems for food Security in Northeast Asia

As reviewed above, the three countries of Korea, China and Japan are all deficit trade balance countries of produce and the deficits increase each year. When the international prices of crops are on the increase, this becomes an anxiety factor to cause the risk of the food safety. Especially, the self- 
Table 11. Food security policies in three countries.

\begin{tabular}{|c|c|}
\hline country & The contents of food security policies \\
\hline Korea & $\begin{array}{l}\text { Law: The Agriculture, Rural Community, and Food Industry Basic Act (2001) } \\
\text {-The goal of food self-sufficient rate } \\
\text {-Calorie-based food self-sufficient rate : } 44 \% \text { in } 2008 \Rightarrow 47 \% \text { in } 2015 \\
\text {-Food security policies in Korea } \\
\text {-Increasing domestic production }+ \text { stable import system }+ \text { agricultural development } \\
\text { overseas + stockpiling }\end{array}$ \\
\hline Japan & $\begin{array}{l}\text { Law: The Food, Agriculture, and Rural Community Basic Act (1999) } \\
\text {-The goal of food self-sufficient rate } \\
\text { - Calorie-based food self-sufficient rate : } 41 \% \text { in } 2008 \Rightarrow 50 \% \text { in } 2020 \\
\text { - Food security policies in Japan } \\
\text {-Increasing domestic production + increasing consumption of domestic food + stable } \\
\text { import system + stockpiling }\end{array}$ \\
\hline China & $\begin{array}{l}\text { Law : The Agriculture Act }(2002) \\
\text {-The goal of food self-sufficient rate } \\
\text {-Maintain more than } 95 \% \\
\text {-Food security policies in Korea } \\
\text {-Increasing domestic production }+ \text { stockpiling }+ \text { export restriction }+ \text { enlargingimport }\end{array}$ \\
\hline
\end{tabular}

Source: Seong (2011).

sufficiency of the soybean in all three countries decreased severely from $62 \%$ in 1980 to $22 \%$ in 2010. In addition, natural disasters frequently occur recently such as flood, drought, typhoon, earthquake, cold-weather damage, etc.

If the geographically close three countries set a cooperation system for food security, when natural disasters cause unstable demand \& supply and food crisis, they can respond together and overcome the crisis. As for the method of food supply, free aid, loan in kind without interest, food loan, and so on are possible and as for the method of repayment, purchase in cash, reimbursement in kind, replacement with other crops and so on are possible.

As shown in Table 11, three countries operate their own policies for food safety. However, the establishment of regional cooperation system is not included.

However, in Asia, recently, a similar entity called 「Project of Rice Reserve in Asia (ASEAN+3 Emergency Rice Reserve: APTERR)」 was established. This project is participated by total 13 countries with 10 ASEAN countries, Korea, China and Japan and was started in 2011 (the agreement was made on Sept. $27^{\text {th }}, 2010$ ).
The project is about reserving rice and selling or loaning it to a country with natural disaster. The reserve size is 787 thousand tons (Korea 150 thousand tons, China 300 thousand tons, Japan 250 thousand tons and ASEAN 87 thousand tons).

The reserve volume is composed of the volume for earmark and that of stockpiling and the earmark is stored in each country and under the advanced agreement among member countries, when the release conditions occur, it is released. The stockpiling is the contributed volume for the rice reserve project and used in emergency or for aid. When the reserve project is executed, the release of rice and the replenishing of the promised volume follow the rules and procedures that the board of directions set.

However, the reserve size of this project is not sufficient for food crisis and flour, corns and beans whose prices keep unstable are excluded and overall, the project is evaluated not sufficient for the regional cooperation for the sake of food security (Seong, 2011).

3) Establishment of agro-valley in Northeast Asia 
Hokkaido of Japan and the 3 northeast provinces of China have great agricultural potentials. If North Korea is included after the re-unification, all of these three areas are located in the north and in proximity and they will have good conditions for the mutual cooperation. Currently, due to the cold weather, some places are not utilized for agriculture sufficiently, but as global warming is advanced, the usable land can be extended.

It is necessary to secure a plan to establish Northeast agriculture cooperation base (Agro-food valley) linking the three areas. By using and extending the concept of food industry cluster or food valley, it is to establish three countries' food production belt specializing in agriculture. Considering the natural resources and features of the three areas, set plans for mutually complementary production and processing of produce and implement the agriculture with the high added value by the input of capital and technology.

Especially, the reinforcement of the cooperation in relation to technologies on environment-friendly agriculture, automation of agricultural materials, machines and facilities, management technology after harvest, food processing in the use of cutting-edge technology, distribution-related information such as selection, logistics, approval, etc., technology system, trade of oil resources, co-development of new items, etc. will contribute to the improvement of the agricultural productivity in this region and in the long-term, to the international competitiveness of agriculture of the three countries.

The agricultural food produced here is prioritized to be supplied to the region and the left one is commonly exported to outside the region and the profit is shared. The unified standards for the quality and safety of agriculture food as mentioned before should be applied to this area first.

\section{4) FTA among Korea, China, and Japan}

Though the FTA among Korea, China and Japan will bring benefits to all three countries, the agreement on the agricultural area will not be easy. Therefore, it is necessary to make a considerate approach and the following issues can be reviewed.

First, it is to implement a model agricultural project. If the agricultural cooperation base as mentioned before is designated as a special place for agricultural opening for three countries and for a few years, the results and problems are reviewed and improved, the trials and errors can be minimized. It is essentially important to build mutual trust through this type of cooperation.

Second, since there is a big difference in the price of the produce between that of China and those of Korea and Japan, it is important to designate the items expected to receive serious damages as sensitive items and give special care not to cause detrimental impacts on the agriculture of the applicable countries. As for other major items, extend the duty-free period for a long term or utilize produce safe guard (ASG) and TRQ amount properly.

Third, 'the low level of FTA' is suggested. It is to gradually extend the opening scope through the continuous discussion after the effectiveness of FTA. Also, 'negotiation for mid-term evaluation' is suggested. That is, after 5-7 years of opening with several items, the evaluation of their impacts is made and the additional negation is conducted.

Fourth, "whether to approve the adaptation to regional conditions in relation to the quarantine of animal/plant (SPS) or not' of WTO defines the occurrence range of animal disease or disease \& insect pest of crops/fruits as 'region' not 'country', so that it can be a big obstacle to the FTA negotiation. Therefore, there should be discussions and mutual understanding on this.

\section{Conclusions}

The three countries of Korea, China and Japan have active trade of agricultural products due to the close 
geographic locations, small-sized agricultural production structure, similarities in the consumption pattern, etc. As the phenomenon of economic block formation is witnessed in all over the world, when the economic cooperation with the agreement of FTA among three countries in the future and so on is reinforced, agricultural trade will be expected to be increased.

However, three countries are in different economic developmental stages and income levels, and their positions for free trade of agricultural products are diverse. In addition, each country's agricultural structure is mutually complementary but at the same time competing to each other, so that the intraregional trade of agricultural products has limitations. These limitations can be obstacles for proceeding the FTA. When tariff and various non-tariff obstacles are removed, there is a high possibility for Chinese produce to monopolize the regional market and the Korean and Japanese agricultural areas are expected to have fierce oppositions.

First, it is necessary for three countries to implement the agricultural cooperation in the method of maintaining the production of competing items at a certain level but extending the trade of complementary items. In addition, through various agricultural cooperation such as continuous development of new items, technology transfer, shared production per agricultural item and so on for the counterpart countries, the preferable division of labor should be established in the industry. When these efforts are accumulated, in the fresh produce area as well as processed produce area, the creation and conversion of the regional trade of produce can be possible.

However, the agricultural cooperation among countries requires not only the economic aspect of efforts but the national leaders' willingness, people's trust and understanding, gradual and elaborate programs and so on. First, it is necessary for three governments to compose a consultative entity in relation to agriculture and make a system to adjust policies and implement them. It is because based on this foundation, the FTA among Korea, China and Japan or the agricultural cooperation in the Northeast Asia is possible.

To activate the agricultural cooperation in the Northeast Asia centering Korea, three northeast provinces of China, and Hokkaido of Japan, the following four issues need to be reviewed in depth.

First, the standards for quality and safety of agricultural food should be unified. If unified standards exist for major tradable items and the goods satisfying these standards are accepted equally in any countries, the regional trade of agricultural food will be more active.

Second, it is desirable to establish a food security cooperation system in the Northeast Asia. If the geographically close three countries set a cooperation system for food security, when natural disasters cause unstable demand \& supply and food crisis, they can respond together and overcome the crisis.

Third, it is necessary to establish Northeast Agricultural Cooperation Base (Agro-valley). By building a food production belt linking Korea (North Korea after re-unification), three northeast provinces of China, and Hokkaido of Japan, agriculture with high added value is implemented from the mutually complementary production/procession of agricultural products.

Fourth, as for the negotiation of agriculture for FTA among Korea, China and Japan, it is desirable to proceed it prudently and first operate a model project by designating 'agricultural cooperation base' as a special place for opening the agriculture of three countries and then, designating the items expected to have detrimental damages as sensitive items and excluding them or extending the duty-free period for a long term and so on. 


\section{References}

aT. 2009. A survey on the situation of Japanese major agricultural products.

aT. 2010. A survey on the import system and export bottlenecks in China.

Choi SK, Heo JN, Lee JH. 2004. Evaluation of Korea-Japan FTA Negotiations for the Agricultural Sector, Korea Rural Economic Institute.

Choi SK, Kwon DH, Chung DH, Hong HP, Jang HS, Kim BT, Ma CM. 2010. Korea-China-Japan FTA and the agro-fisheries sectors: effects and policy implications, Korea Rural Economic Institute.

Choi SK, Lee DS, Joo HJ. 2007. A study on an East Asia FTA for the agricultural sector, Korea Rural Economic Institute.

Choi SK, Shin YS. 2008. East Asia FTA and the agricultural sector, Korea Rural Economic Institute.

Eor MK, Choi SK, Kim TG, Chung CG, Heo JN. 2003. Analyses of Northeast Asian agricultural structure and trade, Korea Rural Economic Institute.

Eor MK, Chung CG, Kim BS, Heo JN. 2004. Effects of Northeast Asian economic cooperation on Korean agriculture, Korea Rural Economic Institute.

Eor MK, Kang HJ, Heo JN, Chung CG. 2005. Establishment of Northeast Asian Economic Cooperation and Strategies for Korean Agriculture, Korea Rural Economic Institute.

Eor MK. 2003. The necessities and possibilities of agricultural cooperation in Northeast Asian region, Korea Rural Economic Institute.

Eor MK. 2012. Korea-China FTA and the countermeasures of agricultural sector, Korea Rural Economic Institute.

Hokkaido Prefecture (Agricultural Policy Sector). 2012. Current status and target of agriculture and rural area in Hokkaido. Japan.

Hwang YJ, Jeon HJ, Han JH. 2010. A study on developing tripartite food safety cooperation among Korea, China, and Japan, Korea Rural Economic Institute.

Iiguni YA. 2010. Strategies of policy cooperation in Northeast Asia, Agriculture and Economy, Showato. Japan.

Jeon HJ, Choi SK, Eor MK, Han SH, Moon HP, Chung DH, Nam MJ, Seung JH. 2011. Analysis of structural change of agricultural trade for an FTA between Korea and China, Korea Rural Economic Institute.

Jeon HJ, Nam MJ, Li NH. 2009. A study on the structural change of rice industry on the varieties of Indica and Japonica type at the three northeastern provinces in China and survey of the situation of production integration, Korea Rural Economic Institute. pp. 29-31.

Jeon HJ. 2012a. Trends of supply and demand and trade of agricultural products in China, Korea Rural Economic Institute. p. 14.

Jeon HJ. 2012b. Agricultural structure of China and trends of agricultural trade between Korea and China(ppt material).

JETRO (Japan External Trade Organization) at Dalian in China. 2010. The current status of Jilin, Liaoning, and Heilongiiang Province. Japan.

Lee BO, Eor MK. 2012. Agriculture in Northeast Asia, Agricultural Economics. pp. 507-529.Yulgok Press, Seoul, Korea.

Lee CJ, Bang HK. 2011. From Northeast Asian economic cooperation to East Asian economic integration, Korea Institute for International Economic Policy.

MAFF (Ministry of Agriculture, Forestry and Fisheries in Japan). 2012. Overview of agricultural export and import.

MIAFF (Ministry for Food, Agriculture, Forestry and Fisheries in Korea). 2006, 2011, 2012. Main Statistics of Agriculture, Forestry, Fisheries, and Food.

Moon HP, Choi SK, Chung DH. 2011. Korea-China agricultural trade: competitiveness \& trade barriers, Korea Rural Economic Institute.

Park JK. 2008. The dilemma of agricultural problems in East Asia and cooperation strategies among Korea, China and Japan in Challenges of the agricultural sector and strategies of cooperation among Korea, China and Japan, KREI (Korea Rural Economic Institute). pp. 72-79.

Seong MH, Lee GC, Lee JW. 2000. Food security strategies in the $21^{\text {st }}$ century, Korea Rural Economic Institute. pp. 87-97.

Seong MH. 2011. Trends of grain supply and demand and food security in Northeast Asia (ppt material), Korea Rural Economic Institute.

Seong MH. 2012. Trends of grain supply and demand and food security cooperation in Northeast Asia (ppt material), Korea Rural Economic Institute. 